\title{
Analisa Pengaruh BOPO, Kecukupan Modal, Pembiayaan Bermasalah, Bagi Hasil Dan Profitabilitas Terhadap Simpanan Mudharabah Pada Bank Umum Syariah
}

Periode 2011-2015

\author{
Sisca Juliana ${ }^{1}$ dan Ade Sofyan Mulazid ${ }^{2}$ \\ ${ }^{1}$ Fakultas Ekonomi dan Bisnis UIN Syarif Hidayatullah Jakarta \\ E-mail:siscajulianal2@gmail.com \\ ${ }^{2}$ Fakultas Ekonomi dan Bisnis UIN Syarif Hidayatullah Jakarta \\ E-mail:adesofyanmulazid@uinjkt.ac.id
}

\begin{abstract}
This study aims to determine the effect BOPO Effect Analysis, Capital Adequacy, Troubled Financing, Sharing and Profitability simultaneously and partially to rate Deposits at Commercial Bank Syariah Mudharabah period 2011-2015. There are nine samples in this study who met the study criteria, namely Bank BCA Syariah, Bank BRI Syariah, Bank BNI Syariah, Bank Muamalat Indonesia, Bank Syariah Mandiri, Bank Mega Syariah, Bank Panin Syariah, Bank Syariah Bukopin and Bank BJB Syariah. The analytical tool used is a panel data regression analysis. The model chosen is Random Effect are tested by $F$ test and $t$ test, with significance level of $5 \%$. Result of test $F$ known that ROA, CAR, NPF, Sharing and ROA simultaneously affect the Deposit Mudharabah Islamic Banks. Based on the test results $t$ is known that, CAR does not affect the Deposit Mudharabah. ROA, NPF, Sharing and ROA significant positive effect on Mudharabah Savings on Islamic Banks. Adjusted R Square in this study indicate that the variable ROA, CAR, NPF, Sharing and ROA in explaining the dependent variable Mudharabah Savings amounted to $66.50 \%$ while the remaining $33.50 \%$ influenced by other independent variables that are not used in this study.
\end{abstract}

Keywords: BOPO, CAR. NPF, Sharing, ROA dan Simpanan Mudharabah.

\begin{abstract}
Abstrak
Penelitian ini bertujuan untuk mengetahui pengaruh Analisa Pengaruh BOPO, Kecukupan Modal, Pembiayaan Bermasalah, Bagi Hasil dan Profitabilitassecara simultan maupun parsial terhadap tingkat Simpanan Mudharabahpada Bank Umum Syariah periode 2011-2015. Terdapat sembilan sampel dalam penelitian ini yang memenuhi kriteria penelitian yaitu Bank BCA Syariah, Bank BRI Syariah, Bank BNI Syariah, Bank Muamalat Indonesia, Bank Syariah Mandiri, Bank Mega Syariah, Bank Panin Syariah, Bank Syariah Bukopin dan Bank BJB Syariah. Alat analisis yang digunakan adalah analisis regresi data panel.Model yang terpilih yaitu Random Effect yang diuji dengan uji $F$ dan uji $t$, dengan tingkat signifikansinya 5\%.Hasil uji F diketahui bahwa BOPO, CAR, NPF, Bagi Hasil dan ROA secara simultan berpengaruh terhadap Simpanan Mudharabah pada Bank Umum Syariah.Berdasarkan hasil uji t diketahui bahwa, CAR tidak berpengaruh terhadap Simpanan Mudharabah.BOPO, NPF, Bagi Hasil dan ROA berpengaruh positif signifikan terhadap Simpanan Mudharabah pada Bank Umum Syariah. Adjusted $R$ Square pada penelitian ini menunjukkan bahwa variabel BOPO, CAR, NPF, Bagi Hasil dan ROA dalam
\end{abstract}


menjelaskan variabel dependen Simpanan Mudharabah sebesar 66.50\% sementara sisanya sebesar 33.50\% dipengaruhi oleh variabel independen lain yang tidak digunakan pada penelitian ini.

Kata Kunci: BOPO, CAR. NPF, Bagi Hasil, ROA dan Simpanan Mudharabah.

\section{A. Pendahuluan}

Bank merupakan badan usaha yang menghimpun dana dari masyarakat dalam bentuk simpanan dan menyalurkannya kepada masyarakat dalam bentuk kredit atau bentuk lainnya dalam rangka meningkatkan taraf hidup rakyat Abdul Ghofur Anshori (2009:226). Dalam dunia modern ini, peranan perbankan dalam memajukan perekonomian suatu Negara sangat besar. Hampir semua sektor yang berhubungan dengan berbagai kegiatan keuangan selalu membutuhkan jasa bank. Oleh karena itu, saat ini dan dimasa yang akan datang kita tidak akan dapat lepas dari dunia perbankan, jika hendak menjalankan aktivitas keuangan, baik perorangan maupun lembaga, baik sosial maupun perusahaan.

Begitu pentingnya dunia perbankan, sehingga ada anggapan bahwa bank merupakan "nyawa" untuk menggerakan roda perekonomian suatu Negara. Anggapan ini tentunya tidak salah karena fungsi bank sebagai lembaga keuangan sangatlah vital, misalnya dalam hal pencetakan uang, mengedarkan uang, tempat mengamankan uang, tempat melakukan investasi dan jasa keuangan lainnya (Kasmir, 2012 : 3).

Bank Islam atau di Indonesia disebut bank syariah merupakan lembaga keuangaan yang berfungsi memperlancar mekanisme ekonomi di sektor riil melalui aktivitas kegiatan usaha (investasi, jual beli atau lainnya) bedasarkan prinsip syariah, yaitu aturan perjanjian berdasarkan hukum Islam antara bank dan pihak lain untuk penyimpanan dana dan atau pembiayaan kegiatan usaha atau kegiatan lainnya yang dinyatakan sesuai dengan nilai-nilai syariah yang bersifat makro maupun mikro (Ascarya, 2007).

Perkembangan kelembagaan bank syariah di Indonesia menunjukkan bahwa amandemen UU Undang-Undang No.10 tahun 1998 tentang Perbankan menjadi UU No.21 tahun 2008 tentang Perbankan Syariah direspon positif oleh pelaku industri perbankan. Sehingga pada tahun 2015, jumlah Bank Umum Syariah yang beroperasi menjadi 12 bank. Eksistensi 
bank syariah juga didorong oleh tingginya jumlah bank syariah di Indonesia minat masyarakat untuk menempatkan mengalami penurunan. Perkembangan dananya di bank syariah dikarenakan bank-bank syariah di dunia dan di produk dana perbankan syariah memiliki Indonesia mengalami kendala dikarenakan daya tarik bagi deposan mengingat nisbah bank syariah hadir di tengah-tengah bagi hasil dan margin produk tersebut perkembangan dan praktik-praktik masih kompetitif dibanding bunga di bank perbankan konvensional yang sudah konvensional. Berikut adalah tabel mengakar dalam kehidupan masyarakat perkembangan bank syariah di Indonesia secara luas. Pesatnya pertumbuhan bank Periode 2011-2015.

Tabel 1

Jumlah Bank Syariah di Indonesia Periode 2011-2015

\begin{tabular}{|c|c|c|c|c|c|}
\hline Indikator & $\mathbf{2 0 1 1}$ & $\mathbf{2 0 1 2}$ & $\mathbf{2 0 1 3}$ & $\mathbf{2 0 1 4}$ & $\mathbf{2 0 1 5}$ \\
\hline Bank Umum Syariah & & & & & \\
\hline Jumlah Bank & 11 & 11 & 11 & 12 & 12 \\
\hline Jumlah Kantor & 1.401 & 1.745 & 1.998 & 2.151 & 2.121 \\
\hline Unit Usaha Syariah & & & & & \\
\hline Jumlah Bank Umum & 24 & 24 & 23 & 22 & 22 \\
\hline Jumlah Kantor & 336 & 517 & 590 & 320 & 327 \\
\hline $\begin{array}{c}\text { Bank Pembiayaan Rakyat } \\
\text { Syariah }\end{array}$ & & & & & \\
\hline Jumlah Bank & 155 & 158 & 163 & 163 & 161 \\
\hline Jumlah Kantor & 364 & 401 & 402 & 439 & 433 \\
\hline Total & 2.291 & 2.856 & 3.187 & 3.107 & 3.076 \\
\hline
\end{tabular}

Sumber : (OJK) Laporan Statistik

Perbankan Syariah, 2015.

Berdasarkan tabel 1 di atas, menunjukkan bahwa perkembangan perbankan syariah berdasarkan laporan tahunan OJK 2015 (Juni 2015). Secara kuantitas, pencapaian perbankan syariah pada tahun 2011-2013 mengalami peningkatan, kecuali pada tahun 2014-2015 syariah di Indonesia juga belum seiring dengan pemahaman dan pengetahuan masyarakat tentang sistem operasional perbankan syariah. Meski demikian, bank syariah terus berkembang setiap tahunnya. Padahal, banyak masyarakat Indonesia yang masih belum mengenal apa dan bagaimana bank syariah menjalankan kegiatan bisnisnya (Dhayattoni, 2013).

Dalam mengatasi kendala perbankan syariah ini, telah dilakukan upaya langkah stategis untuk mengembangkan perbankan syariah salah satunya, yaitu pemberian izin kepada bank umum konvensional untuk membuka kantor cabang Unit Usaha Syariah (UUS) atau konversi sebuah bank konvensional menjadi bank syariah. Langkah strategis ini merupakan respon dan inisiatif dari perubahan UndangUndang No.10 tahun 1998 tentang Perbankan. Undang-Undang pengganti UU 
No.7 tahun 1992 tentang Perbankan suatu pemberian mandat (taukil) dari tersebut mengatur dengan jelas landasan investor (shahibul maal) yang disertakan hukum dan jenis-jenis usaha yang dapat kepada pengelola (mudharib) untuk dioperasikan dan diimplementasikan oleh bank syariah (E-Syariah : 2010).

Ketertarikan masyarakat terhadap budaya menyimpan uang dalam bentuk investasi juga merupakan salah satu faktor penting dalam mengembangkan perbankan syariah. Masyarakat yang memiliki ketertarikan menyimpan uangnya di bank pada dasarnya mengharap keamanan dana atau untuk mendapatkan keuntungan (suku bunga pada bank konvensional dan bagi hasil pada bank syariah). Hal inilah yang diyakini sebagai salah salah satu faktor yang memotivasi masyarakat untuk menyimpan uangnya di bank. Perbankan syariah sendiri berfungsi sebagai agen intermediasi, yang menghimpun dana dari masyarakat dalam bentuk giro (wadi'ah), tabungan (wadiah dan mudharabah), deposito (mudharabah) dan kemudian menyalurkannya lewat pembiayaan (Faizi, 2009).

Salah satu produk yang ditawarkan oleh perbankan syariah adalah dengan menggunakan akad mudharabah. Secara sederhana, pengertian mudharabah menurut ulama fiqh dalam mazhab Maliki adalah berdagang dengan mata uang tunai dengan mendapatkan sebagian keuntungan, jika sudah diketahui jumlah dan keuntungan yang diperolehnya (Indrayani, 2013).

Menurut Undang-Undang No.21 Tahun 2008 tentang Perbankan Syariah, simpanan adalah dana yang dipercayakan oleh nasabah kepada Bank Syariah dan/atau UUS berdasarkan akad wadi'ah atau akad lain yang tidak bertentangan dengan prinsip syariah dalam bentuk giro, tabungan, atau bentuk lainnya yang dipersamakan dengan itu. Simpanan Mudharabah merupakan simpanan yang penarikannya hanya dapat dilakukan menurut syarat tertentu yang disepakati, tetapi tidak dapat ditarik dengan cek atau semacamnya. Mudharabah merupakan prinsip bagi hasil dan bagi kerugian ketika nasabah sebagai pemilik modal (shahibul maal) menyerahkan uangnya kepada bank sebagai pengusaha (mudharib). Keuntungan dibagi sesuai kesepakatan dan kerugian ditanggung oleh pemilik dana atau nasabah (Ascarya, 2007). 
Pada penelitian ini terdapat faktor- kontribusi yang cukup besar bagi faktor penting yang dapat mempengaruhi Profitabilitas. Semakin tinggi tingkat pertumbuhan atau naik turunnya jumlah simpanan mudharabah pada perbankan syariahantara lain, BOPO (Biaya Operasional dan Pendapatan Operasional), Kecukupan Modal, Pembiayaan Bermasalah, Bagi Hasil dan Profitabilitas.

BOPO atau Rasio biaya operasional adalah perbandingan antara biaya operasional dan pendapatan operasional. Rasio biaya operasional digunakan untuk mengukur tingkat efisiensi dan kemampuan bak dalam melakukan kegiatan operasi (Lukman D. Wijaya, 2000 : 120). Semakin rendah BOPO berarti semakin efisien bank tersebut dalam mengendalikan biaya operasionalnya, dengan adanya efisiensi biaya maka keuntungan yang diperoleh bank akan semakin besar.

Modal juga merupakan salah satu faktor penting dalam rangka pengembangan usaha bisnis dan menampung risiko kerugian (Mawardi, 2005). CAR diukur dengan membagi modal dengan aktiva tertimbang menurut risiko (ATMR). Semakin tinggi CAR, maka semakin baik kemampuan bank tersebut untuk menanggung risiko dari setiap kredit atau aset produktif yang berisiko dan mampu memberikan

profitabilitas, maka kelangsungan hidup suatu bank akan lebih terjamin, karena profitabilitas menunjukkan apakah bank tersebut mempunyai prospek yang bagus di masa yang akan datang.

Nilai CAR yang tinggi (sesuai ketentuan BI sebesar 8\%) berarti bank tersebut mampu membiayai operasi bank, keadaan yang menguntungkan bank tersebut akan memberikan kontribusi yang sangat besar bagi simpanan mudharabah dan tentunya akan meningkatkan return simpanan mudharabah yang akan diterima oleh nasabah deposan (Kuncoro \& Suhardjono, 2002: 573).

Non Performing Finance (NPF) atau pembiayaan bermasalah merupakan salah satu indikator kunci untuk menilai kinerja bank. Pembiayaan bermasalah adalah pembiayaan yang pembayaran angsuran pokoknya telah lewat 90 hari setelah jatuh tempo, atau pembiayaan yang pembayarannya secara tepat waktu sangat diragukan. NPF secara luas dapat didefinisikan sebagai suatu pembiayan dimana pembayaran yang dilakukan tersendat-sendat dan tidak mencukupi kewajiban minimal yang ditetapkan sampai 
dengan pembiayaan yang sulit untuk dilunasi atau bahkan tidak dapat ditagih (PSAK No.31 (Revisi 2000) (Ikatan Akutansi Indonesia, 2000).

Bagi hasil menurut terminologi asing (bahasa Inggris) dikenal dengan profit sharing. Profit dalam kamus ekonomi diartikan pembagian laba. Secara definisi profit sharing diartikan "distribusi beberapa bagian dari laba pada pegawai dari suatu Perusahaan." Menurut Antonio, bagi hasil adalah suatu sistem pengolahan dana dalam perekonomian Islam, yakni pembagian hasil usaha antara pemilik modal (shahibul maal) dan pengelola (Mudharib). Secara umum prinsip prinsip bagi hasil dalam perbankan syariah dapat dilakukan dalam empat akad utama, yaitu: musyarakah, mudharabah, muzara'ah dan musaqah (Antonio : 2011).

Nasabah penyimpan dana akan selalu mempertimbangkan tingkat imbalan yang diperoleh dalam melakukan investasi pada bank syariah. Jika tingkat bagi hasil bank syariah terlalu rendah, maka tingkat kepuasan nasabah akan menurun dan kemungkinan besar akan memindahkan dananya ke bank lain. Karakteristik nasabah yang demikian membuat tingkat bagi hasil menjadi faktor penentu kesuksesan bank syariah dalam menghimpun dana pihak ketiga.

Return On Asset (ROA) menurut (Kasmir, 2012:201) adalah rasio yang menunjukan hasil (return) atas jumlah aktiva yang digunakan dalam perusahaan. Selain itu, ROA memberikan ukuran yang lebih baik atas profitabilitas perusahaan karena menunjukan efektivitas manajemen dalam menggunakan aktiva untuk memperoleh pendapatan. Semakin besar Return On Asset (ROA), maka semakin besar pula tingkat keuntungan yang dicapai bank tersebut dan menunjukkan kinerja perusahaan yang semakin baik. Return On Asset (ROA) dipilih sebagai indikator pengukur kinerja keuangan perbankan karena Return On Asset (ROA) digunakan untuk mengukur efektifitas perusahaan didalam menghasilkan keuntungan dengan memanfaatkan aktiva yang dimilikinya Gozali Faruq (2013).

Kelangsungan kegiatan usaha didukung oleh beberapa sumber dana yang dimiliki, seperti simpanan mudharabah. Besarnya simpanan mudharabah terdapat tiga pengaruh pada pembiayaan yang disalurkan. Semakin tinggi nilai simpanan mudharabah, maka semakin besar pembiayaan yang tersalurkan dan 
pemerolehan laba pun meningkat, sehingga dapat diartikan simpanan mudharabah berhubungan dengan profitabilitas (Nur, 2015).

Hasil penelitian terdahulu oleh Permata Ulfa (2016) berjudul Analysis The Effect Of Profitability (ROA), Cost Ratio (BOPO), and Financing To Deposit Ratio (FDR) On The Profit Sharing Mudharabah In Islamic Banking In Indonesia menunjukkan bahwa ROA efek positif yang signifikan pada tingkat keuntungan deposito berbagi mudharabah. Ini berarti bahwa semakin tinggi ROA, semakin tinggi tingkat pendapatan berbagi mudharabah deposito. BOPO menunjukkan hasil yang positif dan signifikan pada tingkat keuntungan bagi deposito mudharabah. Ini berarti bahwa semakin tinggi BOPO, yang tinggi hasil deposito mudharabah. Hasil studi ini bertentangan dengan teori bahwa efisiensi bank syariah dalam biaya dapat menghasilkan pendapatan yang tinggi.BOPO digunakan untuk perhitungan untuk menentukan jumlah biaya yang dikeluarkan oleh bank untuk memperoleh pendapatan, serta untuk mengukur efisiensi kegiatan bank.
Hasil penelitian terdahulu oleh Supitasari (2014) menunjukan bahwa secara bersama-sama Nisbah Bagi Hasil, BI Rate, Inflasi dan NPF (Non Performing Financing) mempunyai pengaruh yang signifikan terhadap Simpanan Mudharabah. Penelitian Nur Maya Kholidah (2015) meneliti perbankan syariah di Indonesia hasilnya menunjukan bahwa Profitabilitas tidak berpengaruh terhadap Simpanan Mudharabah bank syariah di Indonesia.

Penelitian lain dilakukan oleh Nur Hikmah (2009), menunjukan bahwa hanya variabel NPF yang berpengaruh signifikan terhadap Simpanan Mudharabah, sedangkan variable lainnya (ROE, CAR, FDR, dan BOPO) tidak berpengaruh signifikan terhadap Simpanan Mudharabah. Hasil ini membuktikan bahwa risiko pembiayaan bermasalah pada Bank Muamalat Indonesia tidak dalam kondisi yang mengkhawatirkan, dimana tidak terjadi penyimpangan utama dalam tingkat pengambilan atas pembayaran kembali pembiayaan yang diberikan BMI. Hal ini menyebabkan nasabah menginvestasikan dana pihak ketiganya dalam bentuk Simpanan Mudharabah di BMI.

Berdasarkan pada data fenomena yang sudah ada pada penelitian terdahulu dan 
dan banyaknya terjadi fenomena yang tidak sesuai dengan teori yang ada, antara lain nilai ROA (Return On Asset) grafik kenaikan profitabilitas bank syariah yang tidak diikuti dengan kenaikan atau penurunan grafik simpanan mudharabah bank syariah. Kemudian NPF (Non Performing Financing) tidak berpengaruh terhadap simpanan mudharabah, hasil tersebut menunjukan bahwa tinggi rendahnya NPF tidak akan mempengaruhi tinggi rendahnya simpanan mudharabah. Hal ini dikarenakan pihak bank telah memiliki cadangan yang baik dan sudah melakukan analisis resiko yang nantinya permasalahan tersebut tidak akan mempengaruhi besaran dari simpanan mudharabah.

\section{B. Metode Penelitian}

Pada penelitian ini yang dijadikan tempat penelitian adalah Bank Umum Syariah di Indonesia dan penelitian ini dilakukan pada tahun 2016. Penulis menggunakan data penelitian yang bersifat kuantitatif. Menurut Sugiyono (2008) metode kuantitatif adalah pendekatan ilmiah yang memandang suatu realitas itu dapat diklasifikasikan, konkrit, teramati dan terukur, hubungan variabelnya bersifat sebab akibat dimana data penelitiannya berupa angka-angka dan analisisnya menggunakan statistik.

Objek penelitian ini adalah seluruh Bank Umum Syariah yang terdaftar di Bank Indonesia dan dilaksanakan di Bank Umum Syariah dengan melihat tingkat simpanan mudharabah pada laporan keuangan tahunan. Hal ini dimaksudkan agar penelitian ini mampu menjelaskan keadaan yang sebenarnya mengenai faktor-faktor yang mempengaruhi simpanan mudharabah di Bank Umum Syariah pada periode tahun 2011-2015.

Pada penelitian ini variabel independen yang digunakan yaitu Biaya Oprasional terhadap Pendaptan Oprasional $\left(\mathrm{X}_{1}\right)$, Capital Aduquacy Ratio $\left(\mathrm{X}_{2}\right)$, Non Performing Financing $\left(\mathrm{X}_{3}\right)$, Bagi Hasil $\left(\mathrm{X}_{4}\right)$, Return On Asset $\left(\mathrm{X}_{5}\right)$ dan variabel dependen yang digunakan adalah simpanan mudharabah pada Bank Umum Syariah (Y). Data yang digunakan pada penelitian ini adalah data sekunder.

Penelitian ini bersifat asosiatif atau hubungan yang bertujuan untuk mengetahui hubungan antara dua variabel atau lebih.Dari penelitian ini dapat dibangun suatu teori yang berfungsi untuk menjelaskan, meramalkan dan mengontrol suatu gejolak ekonomi (Sugiyono, 2004:29). 
Di samping bersifat asosiatif penelitian ini juga bersifat deskriptif analitik, yaitu menjelaskan mengenai seberapa besar hubungan antara BOPO, CAR, NPF, Bagi Hasil dan ROA terhadap simpanan murabahah pada Bank Umum Syariah periode 2011-2015.

Adapun model persamaan regresi dengan menggunakan data panel yang digunakan pada penelitian ini adalah sebagai berikut:

$Y=\beta_{0}+\beta_{1} X_{1}+\beta_{2} X_{2}+\beta_{3} X_{3}+\beta_{4} X_{4}+\beta_{5} X_{5}+e$

Keterangan :

$\mathrm{Y}=$ Simpanan Mudharabah

$\beta_{0}=$ Konstanta

$\beta_{1}, \beta_{2}, \beta_{3}, \beta_{4}, \beta_{5}=$ Koefisien masing-masing variabel

$\mathrm{X}_{1}=$ Biaya Oprasional terhadap Bebab

Oprasional (BOPO)

$\mathrm{X}_{2}=$ Kecukupan Modal (CAR)

$\mathrm{X}_{3}=$ Pembiayaan Bermasalah (NPF)

$\mathrm{X}_{4}=$ Dana Pihak Ketiga (DPK)

$\mathrm{X}_{5}=$ Retun On Asset (ROA)

$\mathrm{e}=$ Disturbance Error

\section{Pemilihan Model Estimasi Regresi Data Panel}
a. Uji Chow
Untuk membandingkan atau memilih model mana yang terbaik dapat

dilihat dari nilai probabilitas (Prob.) untuk Cross-section F. Jika nilainya > 0,05 (ditentukan di awal sebagai tingkat signifikansi atau alpha) maka model yang terpilih adalah Common Effect, tetapi jika $<0,05$ maka model yang terpilih adalah Fixed Effect.

\section{b. Uji Hausman}

Uji Hausman dilakukan untuk membandingkan atau memilih model mana yang terbaik antara Fixed Effect dan Random Effect. Untuk membandingkan atau memilih model mana yang terbaik dapat dilihat dari nilai probabilitas (Prob.) Cross-section random. Jika nilainya > 0,05 maka model yang terpilih adalah Random Effect, tetapi jika < 0,05 maka model yang terpilih adalah Fixed Effect Iqbal (2016).

\section{Pengujian Asumsi Klasik}

a. Uji Normalitas

Uji Normalitas bertujuan untuk menguji apakah dalam model regresi, variabel pengganggu atau residual memiliki distribusi normal. Seperti diketahui bahwa uji $t$ dan $F$ mengasumsikan bahwa nilai residual mengikuti distribusi normal.Kalau asumsi ini dilanggar maka uji statistik 
menjadi tidak valid untuk jumlah sampel kecil Imam Gozali (2016:154).

b. Uji Autokorelasi

Untuk mengidentifikasi autokorelasi menggunakan dua cara, yaitu dengan Uji Durbin-Watson dan Uji Breusch-Godfrey. Namun, dalam penelitian ini untuk mengetahui ada atau tidaknya autokorelasi dideteksi dengan $\mathrm{Uji}$ Breusch-Godfrey. Nama lain uji BG ini adalah Uji Lagrange-Multiplier (Pengganda Lagrage). Untuk melakukan Uji BreuschGodfrey, dapat dilihat nilai Obs*R-squared dan nilai probability di sebelah kanannya. Bila nilai probability> $\alpha=5 \%$, maka tidak ada autokorelasi. Bila nilai probability $<\alpha=$ $5 \%$, maka terdapat autokorelasi.

c. Uji Multikolinieritas

Uji Multikolonieritas bertujuan untuk menguji apakah model regresi ditemukan adanya kolerasi antar variabel bebas (independen). Uji koefisien kolerasinya yang mengandung unsur multikolinieritas, misalnya $X_{1}$ dan $\mathrm{X}_{2}$. Langkah-langkah pengujian sebagai berikut:

$\begin{array}{lllll}\text { Bila } & \mathrm{r} & >0,85 & \text { (tidak ada }\end{array}$ multikolinieritas)

Bila $r<0,85$ (ada multikolinieritas). d. Uji Heteroskedastisitas

Untuk mengetahui ada tidaknya masalah heteroskedastisitas melalui uji White dengan melihat nilai probabilitasnya. Jika probabilitasnya lebih kecil dari tingkat signifikansi 0,05 $(\alpha=5 \%)$ sehingga signifikan. Artinya tidak menolak hipotesis nol atau menerima hipotesis alternatif. Jika menolak hipotesis nol berarti heteroskedastisiras, berarti model mengandung masalah heteroskedastisitas Widarjono (2010 : 91).

\section{Uji Hipotesis}

Pengujian hipotesis dalam penelitian ini menggunakan uji f untuk uji simultan dan Uji t untuk uji parsial.

\section{a. Uji Simultan (Uji Statistik F)}

Nilai F kritis berdasarkan besarnya $\alpha$ dan df dimana besarnya ditentukan oleh :

$\mathrm{dfl}=\mathrm{k}-\mathrm{l}$

$\mathrm{df} 2=\mathrm{n}-\mathrm{k}$

$\mathrm{k}=$ adalah jumlah parameter estimasi termasuk konstanta.

$\mathrm{n}=$ adalah jumlah observasi.

Jika F hitung > F kritis, maka kita menolak $\mathrm{H}_{0}$ berarti secara bersama- 
sama variabel independen akan selalu berada di antara 0 dan 1 , berarti mempengaruhi variabel dependen. semakin besar kemampuan variabel jika $F$ hitung < $F$ kritis maka independen untuk menjelaskan menerima $\mathrm{H}_{0}$ yang berarti secara (pengaruhnya) kepada variabel dependen bersama-sama semua variabel Winarno (2015).

independen tidak mempengaruhi variabel dependen. (Widarjono, $2010: 24)$.

b. Uji Parsial (Uji Statistik t)

Uji statistik t pada dasarnya menunjukkan seberapa jauh pengaruh satu variabel penjelas atau independen secara individual dalam menerangkan variasi variabel dependen (Gozali : 2016 : 97).

Membandingkan nilai $t$ hitung dengan t kritisnya. Keputusan menolak atau menerima $\mathrm{H}_{0}$ sebagai berikut (Widarjono : $2010: 26$ ):

Jika niai $t$ hitung > nilai $t$ kritis maka $\mathrm{H}_{0}$ ditolak atau menerima $\mathrm{H}_{a}$ yang artinya signifikan

Jika nilai $t$ hitung < nilai $t$ kritis maka $\mathrm{H}_{0}$ diterima atau menolak $\mathrm{H}_{a}$ yang artinya tidak signifikan.

\section{Koefisien Determinasi $\left(\mathrm{R}^{2}\right)$}

Nilai koefisien determinasi (Adj R²) menunjukan kemampuan model untuk menjelaskan hubungan antara variabel independen dan variabel dependen. Nilai $\mathrm{R}^{2}$

\section{Hasil dan Pembahasan}

Dari hasil penelitian dengan menggunakan data panel, maka hasilnya adalah sebagai berikut :

Tabel 2

Hasil Analisa Pengaruh

\begin{tabular}{|c|c|c|}
\hline Variabel & thitung & Probabilitas \\
\hline BOP0 & 2.937533 & 0.0057 \\
\hline CAR & 0.828377 & 0.4128 \\
\hline NPF & 3.204475 & 0.0028 \\
\hline Bagi Hasil & 4.323963 & 0.0001 \\
\hline ROA & 4.114078 & 0.0002 \\
\hline
\end{tabular}

Sumber : Hasil Olah Data (E-views 8)

\section{Pengaruh BOPO terhadap Simpanan} Mudharabah

Berdasarkan hasil penelitian, variabel $\mathrm{BOPO}$ tidak memiliki pengaruh terhadap Simpanan Mudharabah pada Bank Umum Syariah dalam periode 2011 hingga 2015. Hal ini dapat dilihat dari table 2 yang menunjukkan bahwa tingkat probabilitas BOPO sebesar 0.0057 lebih kecil dari tingkat signifikansi yang digunakan yaitu 0.05 (5\%), sehingga dapat dipastikan 
bahwa BOPO berpengaruh terhadap simpanan mudharabah.

Tabel tersebut menjelaskan bahwa hal ini sesuai dengan teori yang menyatakan semakin besar rasio BOPO, maka semakin tidak efisien suatu bank. Efisiensi bank dikatakan membaik ditunjukan oleh penurunan nilai BOPO. Semakin kecil rasio BOPO berarti semakin efisien beban operasional yang dikeluarkan bank yang bersangkutan, sehingga kemungkinan suatu bank dalam kondisi bermasalah semakin kecil. Dengan demikian, nasabah tertarik untuk menghimpun dananya di bank syariah dalam bentuk simpanan mudharabah.

\section{Pengaruh CAR terhadap Simpanan Mudharabah}

Berdasarkan hasil penelitian, variabel CAR tidak memiliki pengaruh terhadap Simpanan Mudharabah pada Bank Umum Syariah dalam periode 2011 hingga 2015. Hal ini dapat dilihat dari table 2 yang menunjukkan bahwa tingkat probabilitas CAR sebesar 0.4128 lebih besar dari tingkat signifikansi yang digunakan yaitu 0.05 (5\%), sehingga dapat dipastikan bahwa CAR tidak berpengaruh terhadap simpanan mudharabah.
Tabel tersebut menjelaskan bahwa hal ini tidak sesuai dengan teori yang menyatakan semakin tinggi CAR maka semakin, baik kemampuan bank tersebut untuk menanggung risiko dari setiap atau aktiva produktif yang berisiko. Jika nilai CAR tinggi maka bank tersebut mampu membiayai kegiatan operasional dan memberikan kontribusi yang cukup besar. Dalam penelitian ini CAR yang tinggi dapat mengurangi kemampuan bank dalam melakukan ekspansi usahanya karena semakin besarnya cadangan modal yang digunakan untuk menutupi risiko kerugian. Terhambatnya ekspansi usaha akibat tingginya CAR yang pada akhirnya akan mempengaruhi kinerja keuangan bank tersebut.

\section{Pengaruh NPF terhadap Simpanan Mudharabah}

Berdasarkan hasil penelitian, variabel NPF memiliki pengaruh terhadap Simpanan Mudharabah pada Bank Umum Syariah dalam periode 2011 hingga 2015. Hal ini dapat dilihat dari tabel 2 yang menunjukkan bahwa tingkat probabilitas NPF sebesar 0.0028 lebih kecil dari tingkat signifikansi yang digunakan yaitu 0.05 (5\%), sehingga dapat dipastikan bahwa 
NPF berpengaruh terhadap simpanan mudharabah.

Hal tersebut menjelaskan bahwa jika semakin tinggi NPF maka akan semakin buruk kualitas kredit bank yang menyebabkan jumlah kredit bermasalah semakin besar maka kemungkinan suatu bank dalam kondisi bermasalah semakin besar. Sebaliknya jika NPF rendah maka kondisi bank semakin baik, sehingga nasabah tidak ragu untuk menghimpun dananya di Bank Syariah dalam bentuk simpanan mudharabah.

\section{Pengaruh Bagi Hasil terhadap Simpanan Mudharabah}

Berdasarkan hasil penelitian, variabel bagi hasil memiliki pengaruh terhadap Simpanan Mudharabah pada Bank Umum Syariah dalam periode 2011 hingga 2015. Hal ini dapat dilihat dari tabel 2 yang menunjukkan bahwa tingkat probabilitas Bagi Hasil sebesar 0.0001 lebih kecil dari tingkat signifikansi yang digunakan yaitu 0.05 (5\%), sehingga dapat dipastikan bagi hasil berpengaruh terhadap simpanan mudharabah.

Hal tersebut menjelaskan bahwa jika bagi hasil yang ditawarkan oleh bank syariah kepada nasabah maka akan meningkatkan jumlah simpanan mudharabah yang dihimpun bank syariah karena para nasabah pada umumnya menabungkan dananya pada bank syariah dikarenakan mereka masih mencari keuntungan.

\section{Pengaruh ROA terhadap Simpanan} Mudharabah

Berdasarkan hasil penelitian, variabel ROA memiliki pengaruh terhadap Simpanan Mudharabah pada Bank Umum Syariah dalam periode 2011 hingga 2015. Hal ini dapat dilihat dari tabel 2 yang menunjukkan bahwa tingkat probabilitas sebesar 0.0002 lebih kecil dari tingkat signifikansi yang digunakan, yaitu 0.05 (5\%), sehingga dapat dipastikan bahwa variabel ROA berpengaruh terhadap simpanan mudharabah.

Hal tersebut menjelaskan bahwa jika ROA meningkat, maka pendapatan bank juga akan meningkat, sehingga return yang diterima oleh nasabah dan investor (pemegang saham) juga meningkat. Dengan demikian, dapat dikatakan bahwa semakin tinggi ROA, maka return yang diterima oleh nasabah dan investor juga semakin tinggi.

\section{Kesimpulan}

Berdasarkan pada pengujian yang telah dilakukan terhadap beberapa 
hipotesis dalam penelitian, hasilnya menunjukkan bahwa tidak semua variabel independen tersebut dapat mempengaruhi variabel dependen. Hasil Penelitian dapat ditarik kesimpulan sebagai berikut:

1. Berdasarkan individu (Parsial) Biaya Oprasional Terhadap Pendapatan Oprasional (BOPO) berpengaruh terhadap Simpanan Mudharabah pada Bank Umum Syariah Periode 2011-2015.

2. Berdasarkan individu (Parsial) Capital Adequacy Ratio (CAR) tidak berpengaruh terhadap Simpanan Mudharabah pada Bank Umum Syariah Periode 2011-2015.

3. Berdasarkan individu (Parsial) Non Performing Finance (NPF) berpengaruh terhadap Simpanan Mudharabah pada Bank Umum Syariah Periode 2011-2015.

4. Berdasarkan individu (Parsial) Bagi Hasil berpengaruh terhadap Simpanan Mudharabah pada Bank Umum Syariah Periode 2011-2015.

5. Berdasarkan individu (Parsial) Return On Asset (ROA) berpengaruh terhadap Simpanan Mudharabah pada Bank Umum Syariah Periode 2011-2015.

6. Kinerja keuangan yang terdiri dari BOPO, CAR, NPF, Bagi Hasil dan ROA berpengaruh secara simultan terhadap
Simpanan Mudharabah pada Bank Umum Syariah periode 2011-2015.

Kesimpulan di atas, merupakan kesimpulan sementara yang memerlukan penelitian lebih lanjut untuk mendapatkan hasil yang lebih akurat karena adanya keterbatasan, seperti data, waktu dan pengetahuan penulis. Adapun yang dapat dijadikan masukan adalah sebagai berikut :

1. Bagi Perbankan Syariah

Bank Syariah agar lebih meningkatkan pelayanan (jasa-jasa) sehingga masyarakat agar lebih tertarik untuk menabung di Perbankan Syariah. Diharapkan Bank Syariah dapat lebih mensosialisasikan keberadaan kepada masyarakat khususnya yang ada di pelosok-pelosok daerah.

2. Bagi Stakeholder

Bagi masyarakat atau stakeholders dalam menginvestasikan dananya, hendaknya mempertimbangkan besar kecilnya pendapatan dan tingkat bagi hasil yang ditetapkan oleh pihak bank. Berdasarkan penelitian pendapatan dan tingkat bagi hasil berpengaruh terhadap simpanan mudharabah, sehingga keuntungan yang diperoleh oleh stakeholders dapat maksimal. 
3. Bagi Peneliti Selanjutnya

a. Diharapkan penelitian lain dapat menambah waktu penelitian yang lebih panjang sehingga hasil penelitian lebih akurat.

Diharapkan untuk peneliti selanjutnya dapat menambah variabel independen atau mengganti variabel independen yang tidak signifikan dengan faktor-faktor lain yang mungkin dapat mempengaruhi tingkat simpanan mudharabah bank umum syariah.

\section{DAFTAR PUSTAKA}

A. Perwataatmadja. Karnaen, Muhammad Syafi'i Antonio" Apa dan Bagaimana Bank Islam," Dana Bhakti Wakaf. Yogyakarta. 1992.

Abidin, Muh. Hadi. 2014. Pengaruh CAR, BOPO, dan LDR terhadap ROA pada Bank Umum Swasta Nasional di Indonesia. Skripsi: Program Sarjana Fakultas Ekonomi dan Bisnis Jurusan Manajemen Universitas Hasanudin Makassar.

Ach. Bakhrul Muchtasib. Konsep Bagihal.asil Dala Perbankan Syariah. 2006. (www.google.com).

Achmad, T. Kusuno. "Analisis Rasio-rasio Keuangan sebagai Indikator dalam Memprediksi Poternsi Kebangkrutan Perbankan Indonesia", Media Ekonomi dan Bisnis. Vol XV. No. 1. Jakarta. 2003.
Agista, Aristanti Radis, 2015. Analisis Pengaruh DPK, CAR, NPF dan ROA Terhadap Pembiayaan di PT Bank Muamalat Indonesia Tbk. Periode 2007-2013. Skripsi Program Studi Sl, Universitas Muhammadiyah Surakarta: Surakarta. Dipublikasikan

Agus Farianto. "Hasil Pengaruh Return On Asset (ROA), BOPO dan BI-RATE Terhadap Tingkat Bagi Hasil Deposito Mudharabah Pada Bank Umum Syariah Di Indonesia Tahun 2012-2012", Sekolah Tinggi Agama Islam Negri (STAIN). Kudus. 2013.

Agustianto. "Penentuan Bagihal.asil Deposito Mudharabah Di Bank Syariah". (www.iaei-pusat.net email: agusmingka66@yahoo.com)

Almilia, Luciana Spica dan Winny Herdiningtyas." Analisa Rasio Camel terhadap Prediksi Kondisi Bermasalah pada Lembaga Perbankan Periode 2000-2002", Jurnal Akuntansi dan Keuangan. Volume 7 Nomor 2, STIE Perbanas. Surabaya. 2005.

Akhyar Adnan. (2005). Analisis Hubungan Simpanan, Modal Sendiri, NPL, Prosentase Bagi Hasil, dan Mark Up Keuntungan Terhadap Pembiayaan Pada Perbankan Syariah. Kajian Bisinis dan Manajemen.

Al-Ansari, Muhammad Ibn Ahmad Ibn Zakariyya.tt. Fath al-Wahab. Dar Al-Kutub Al-Alamiyah. Beirut.

Al-Husayni, Taqiyyuddin Abu Bakr.tt. Kifayah al-Akhyar. PT. Al-Ma'arif. Bandung. 
Amelia, Rizky, 2011. Pengaruh CAR, FDR, dan NPF Terhadap Return Bagi Hasil Deposito Mudharabah Pada Perbankan syariah, Skripsi SI Fakultas Syariah dan Hukum UIN Syarif Hidayatullah Jakarta.

Andriyani, Isna. "Analisis Pengaruh ROA, BOPO dan Suku Bunga Terhadap Tingkat Bagi Hasil Deposito Mudharabah," Skripsi. UPN "Veteran Yogyakarta".Yogyakarta. 2012.

Anshori, Abdul Ghofur. "Perbankan Syariah Indonesia", Gadjah Mada University Press. Yogyakarta. 2009.

Antonio, Syafi'I."Bank Syariah Dari Teori Ke Praktek", Gema Insani Press, Jakarta. 2001.

Antonio, Muhammad Syafi'i."Bank Syariah Dari Teori Ke Praktek", Gema Insani Press Bekerjasama dengan YayasanTazkia Cendekia, Jakarta. 20011.

Arianti, Wuri N.P dan Harjun Muharam. 201l. Analisis Pengaruh Dana Pihak Ketiga (DPK), Capital Adequacy Ratio (CAR), Non Performing Financing (NPF) dan Return On Asset (ROA) Terhadap Pembiayaan Pada Perbankan Syariah.

Arni, Muhammad. "Komunikasi Organisasi", Bumi Aksara. Jakarta. 2005.

Apriada, Kadek. 2013. "Pengaruh Struktur Kepemilikan Saham, Struktur Modal dan Profitabilitas pada Nilai Perusahaan". Tesis, Universitas Udayana.

Apriandika, Rangga. 2011. Analisis Hubungan Kinerja Keuangan
Terhadap Tingkat Bagi Hasil Simpanan Mudharabah Pada Bank Syariah. Jurnal. Universitas Lampung.

Ascarya. "Akad dan Produk Bank Syariah". PT. Raja Grafindo Persada. Cetakan ke-3. Jakarta. 2011.

Bambang Sudiyatno, Jati Suroso. 2010. Analisis Pengaruh Dana Pihak Ketiga, BOPO, CAR, dan LDR Terhadap Kinerja Keuangan Pada Sektor Perbankan Yang Go Public di Bursa Efek Indonesia. Universitas Stikubank Semarang.

Bastian.Suhardjono. "Akuntansi Perbankan". Salemba Empat. Jakarta. 2006.

Bintang, Andika. 2013. Analisis Pengaruh Non Performing Finance Pembiayaan Murabahah, Pembiayaan Mudharabah dan Pembiayaan Musyarakah Terhadap Profitabilitas Dengan Menggunakan Pendekatan Return On Assets (ROA) Pada Bank Umum Syariah. Skripsi Program Studi Sl, Universitas Pembangunan Nasional "Veteran" Jawa Timur. Dipublikasikan

Dini, Astrid Wulan dan Iin Indarti. 2012. "Pengaruh Net Profit Margin (NPM), Return on Asset (ROA), danReturn on Equity terhadap Harga Saham dalam Indeks Emiten LQ45 tahun 2008-2010", Jurnal Kajian Akutansi dan Bisnis Vol. 1 No. 1.

Dendawijaya Lukman. "Manajemen Perbankan", Ghalia Indonesia Edisi Kedua. Jakarta. 2003. 
Dhayattoni."Sejarah dan Perkembangan Bank Syariah Di Indonesia", Jurnal. Jakarta. 2013.

Dhian Dayinta Pratiwi. "Pengaruh CAR, BOPO, NPF dan FDR Terhadap Return On Asset (ROA) Bank Umum Syariah". Jakarta 2015.

Fahmy, M. Shalahuddin. 2013. Pengaruh CAR, NPF, BOPO, dan FDR, Terhadap Profitabilitas Bank Umum Syariah. Skripsi Program Studi Sl, Universitas Islam Negeri Sunan Kalijaga: Yogyakarta. Dipublikasikan.

Fatimah, Siti. 2014. Pengaruh KAS, SBIS, CAR, DPK, dan NPF Terhadap Pembiayaan Murabahah (Studi Empiris pada BMI, BSM dan BRIS). Skripsi, Universitas Muhammadiyah Yogyakarta.

Fakhrurrazy. "Fungsi Sistem Keuangan", Jurnal. Jakarta. 2009.

Firdha, Roikhatul Jannah. "Pengaruh Profit Sharing, Financing To Deposit Ratio (FDR), capital Adequacy Ratio (CAR), Suku Bunga dan Inflasi Terhadap Jumlah SImpanan Mudharabah Pada Bank Umum Syariah (Periode 2007-20011)", Skripsi, UIN Sunan Kalijaga Yogyakarta. 2012.

Ghozali, Faruq. 2013."Pengaruh Return on Asset (ROA), Earning Per Share (EPS), dan Debt to Equity Ratio terhadap Harga Saham (Studi pada Perusahaan Properti yang Listing di Bursa Efek Indonesia Tahun 2007-2011)". Jurnal Ilmiah Mahasiswa FEB Vol. 1 No. 2.
Ghozali, Imam. "Aplikasi Analisis Multivariete", Badan Penerbit Universitas Diponogoro. Semarang. 2013.

Gujarati, Damodar N, "Basic Econometrics, 4rd ed", McGraw-Hill, New York, 2004.

Hamid, Abdul. "Pasar Modal Syariah", Lembaga Penelitian UIN Jakarta, Jakarta, 2009.

Hamonangan, Jefri dan T, Dyah Nirmalawati, 2008. Efektifitas Promosi Terhadap Peningkatan Dana Pihak Ketiga Pada PT. Bank Rakyat Indonesia. National Conference On Management Research.

Hasan, Ghufran. 2014. Pengaruh Dana Pihak Ketiga, Non Performing Financing, Rasio Biaya, Capital Adequacy Ratio, Financing To Deposit Ratio, dan Ukuran Perusahaan Terhadap Profitabilitas Bank Umum Syariah. Program Studi Sl, Universitas Islam Negeri Sunan Kalijaga: Yogyakarta. Dipublikasikan.

Hasanuzzaman, M.S.1995. Islamic Law and Finance on Encyclopaedia of Islamic Banking and Insurance. Institute of Islamic Banking and Insurance. London.

Hedy Kuswanto dan M. Taufiq.“Pengaruh Dana Pihak Ketiga Terhadap Kredit Pada Bank Perkreditan Rakyat Di Indonesia”.Jurnal. Jakarta. 2011.

Hikmah, Nur. "Analisa Pengaruh Kinerja Keuangan Bank Terhadap Simpanan Mudharabah Perbankan Syariah Di Indonesia" Skripsi. UIN Syarif Hidayatullah. Jakarta. 2009. 
Hikmah.Nurul, "Analisis Pengaruh ROA, BOPO, NPF dan FDR Terhadap Tingkat Bagi Hasil Deposito Mudharabah", UIN Sunan Kalijaga, Yogyakarta.Yogyakarta. 2015.

Indonesia. Undang-Undang tentang Perubahan atas Undang-Undang No.7 Tahun 1992 tentang Perbankan. UU No. 10 Tahun 1998 tentang Perbankan, LN No. 182 Tahun 1998, TLN No. 3790.

Indrayani. "Pengaruh Kinerja Keuangan Terhadap Tingkat Bagi Hasil Simpanan Mudharabah Pada Bank Syariah”.Skripsi. Lampung. 2013.

Ibn Qudamah, Ibn Abi Muhammad Abdullah Ibn Ahmad.1994. Kitab alMughni. Maktabah al-Raiyad alHadithah. Riyad.

Ismail, Manajemen Perbankan dari Teori menuju Aplikasi, Edisi pertama, Cetakan pertama, (Jakarta: Prenadamedia, 2010).

Isnaini, Dwi, 2009. Pengaruh Capital Adequacy Ratio, Non Performing Fianancing, Beban Operasional Per Pendapatan dan Financing to Deposito Ratio Terhadap Perubahan laba pada Bank Umum Syariah Indonesia tahun 2005-2007, Skripsi Fakultas Syariah Universitas Islam Negeri Sunan Kalijaga Yogyakarta.

Juwariyah, Siti. 2008. “Analisis Pengaruh Profitabilitas dan Efisiensi terhadap tingkat bagi hasil tabungan dan Deposito Mudharabah Muthlaqah Studi Bank Muamalat Indonesia", Skripsi UIN Sunan Kalijaga. Yogyakarta.
Kasmir, 2012, Analisis Laporan Keuangan, PT. Raja Grafindo Persada, Jakarta.

Kasmir, Dasar-dasar Perbankan-Edisi Revisi 2014, Cetakan Kedua belas, (Jakarta: Rajawali Pers, 2014).

Kasmir. "Dasar-dasar Perbankan". PT. Rajagrafindo Persada, Jakarta, 2012.

Kholidah. Nur Maya, "Analisis Pengaruh Simpanan Mudharabah, CAR, FDR, Pembiayaan, NPF dan BOPO Terhadap Profitabilitas Perbankan Syariah di Indonesia (Periode Tahun 2010-2014)", Universitas Negri Surabaya. Surabaya. 2015.

Khasanah, Ulfa, 2012. "Analisis Pengaruh Pendapatan Bank, DPK, dan ROA Terhadap Profit Sharing Deposito Mudharabah pada PT Bank Syariah Mandiri Tahun 2008-201l", Skripsi Fakultas Syariah Institut Agama Islam Negeri Walisongo Semarang.

Khumas, M. Salih. "Bir Finansman Modeli Olarak Mudârabe'bin Faizsiz Bankacılıkta Etkin Şekilde Kullanılması Sürecinde Sivil Toplum Örgütlerinin Aktif Rol Üstlenmesî̂.”Jurnal.Turki. 2015.

Kuncoro, Mudrajad, "Ekonomi Pembangunan, Teori Masalah dan Kebijakan". UPP AMP YKPN, Yogyakarta. 2000.

Kuncoro dan Suhardjono, "Manajemen Perbankan (Teori dan Aplikasi)", Edisi Pertama, Penerbit BPFE, Yogyakarta. 2002.

Laksitarini. Nidya, "Pengaruh Return on Asset (ROA), Capital Adequacy Ratio (CAR), Biaya Operasional terhadap Pendapatan Operasional (BOPO), Terhadap Tingkat Bagi Hasil Deposito Mudharabah Pada 
Bank Umum Syariah" Fakultas ekonomika dan Bisnis UGM. Yogyakarta. 2013.

Leman. "Analisa Hubungan Kinerja Keuangan Dengan Tingkat Bagi Hasil Simpanan Mudharabah Bank Syariah”. Skripsi Jakarta. 2012.

Louis Ma'luf, Al-Munjid fi al-Lughah, Beirut: Dar al-Masyriq, Lebanon, 1986.

Lukman, Dendawijaya. "Manajemen Perbankan". Ghalia Indonesia. Jakarta. 2000.

Lukman, Dendawijaya. "Manajemen Perbankan". Ghalia Indonesia. Jakarta. 2000

Lukman, Dendawijaya. "Manajemen Perbankan". Edisi Kedua, Cetakan Kedua, Ghalia Indonesia, Bogor Jakarta. 2005.

M. Salih Kumas. "Bir Finansman Modeli Olarak Mudârabe'bin Faizsiz Bankacilıkta Etkin Şekilde Kullanılması Sürecinde Sivil Toplum Örgütlerinin Aktif Rol Üstlenmesiî. Jurnal. Turki. 2015.

Mahmoeddin, As Haji. "Melacak Kredit Bermasalah" Pustaka Sinar Harapan. Jakarta. 2004.

Malayu S.P. Hasibuan. "Dasar-Dasar Perbankan", Bumi Aksara. Jakarta. 2008.

Masturoh.Siti, "Pengaruh Return Bagi Hasil (Mudharabah) terhadap Dana Pihak Ketiga (DPK) Pada Bank Muamalat Indonesia", UIN Syarif Hidayatullah. Jakarta. 2011.
Maula, Khodijah Hidayatul. 2008. Pengaruh Simpanan (Dana Pihak Ketiga), Modal Sendiri, Marjin Keuntungan Dan NPF (Non Performing Financing) Terhadap Pembiayaan Murabahah Pada Bank Syariah Mandiri. Skripsi Program Studi Sl, Universitas Islam Negeri Sunan Kalijaga: Yogyakarta. Dipublikasikan.

Mawardi, Wisnu. 2005. "Analisis FaktorFaktor yang Mempengaruhi Kinerja Keuangan Bank Umum di Indonesia (Studi Kasus Pada Bank Umum Dengan Total Assets Kurang dari 1 Triliun)", Jurnal Bisnis Strategi, Vol. 14, No. 1.

Mawardi, Nasrah. 2008. "Faktor-faktor yang Mempengaruhi Penetapan Return Bagi Hasil Deposito Mudharabah Muthlaqah: Studi pada Unit Syari'ah Bank X",Jurnal Eksis,Vol. 4.

Ma"luf, Louis.1986. al-Munjid. Darul Masyrik. Beirut.

Mesra Wahyuni, (2014) Pengaruh CAR, FDR, NPF, BOPO, INFLASI, ROA dan Tingkat Suku Bunga Terhadap Return Bagi Hasil Deposito Mudharabah Pada Bank Umum Syariah Periode 2010-2013. Skripsi, Universitas Negeri Sultan Syarif Kasim Riau.

Medy Tama Prihartadi, "Pengaruh Dana Pihak Ketiga dan Tingkat Bagi Hasil Terhadap Pembiayaan Mudharabah", Skripsi. Surabaya. 2016.

Mudrajad, Kuncoro. "Manajemen Perbankan". BPFE. Yogyakarta. 2002. 
Muhammad, "Teknik Perhitungan Bagihal.asil di Bank Syariah.” (Yogyakarta, UII Press, 2001).

Muhammad. "Teknik Perhitungan Bagi Hasil dan Profit Margins Pada Bank Syariah".Cet. Ke-2, Edisi Revisi, Yogyakarta, 2004.

Muhammad Syafi'i Antonio, Bank Syariah dari teori ke praktik,(Jakarta: Gema Insani, 2011)hlm. 90

Mulazid, Ade Sofyan. "Kedudukan Sistem Pegadaian Syariah Dalam Sistem Hukum Nasional Di Indonesia" Jakarta. 2012.

Mutamimah dan Siti NUr Zaidah Chasanah. 2012. Analisis Eksternal Dan Internal Dalam Menentukan Non Performing Financing Bank Umum Syariah Di Indonesia. Jurnal Bisnis dan Ekonomi. Vol. 19, No.l, Maret 2012.

Nainggolan, Marnov. 2009. "Analisis LDR, NIM, BOPO Terhadap ROA Bank Umum Indonesia", Skripsi Universitas Sumatera Utara. Medan.

Nachrowi, Djalal Nachrowi, Hardius Usman. "Pendekatan Populer dan Praktis Ekonometrika untuk Analisis Ekonomi dan Keuangan". Lembaga Penerbit Universitas Indonesia, Jakarta, 2006.

Nugraha, Fajar Adhi. 2014. Faktor-faktor Yang Mempengaruhi Non Performing Financing Pada Perbankan Syariah di Indonesia. Jurnal ilmiah: tidak dipublikasikan.

Nur, Hakimah. "Analisa Pengaruh Kinerja Keuangan Bank Terhadap Simpanan
Mudharabah Perbankan Syariah Di Indonesia", Skripsi. Jakarta. 2009.

Permana, Rika Ariyanti. 2014. Pengaruh Dana Pihak Ketiga (DPK) Dan Non Performing Loan (NPL) Terhadap Return On Assests (ROA) Pada Sektor Perbankan Yang Terdaftar Di Bursa Efek Indonesia Periode 2010-2013. Skripsi Program Studi Akuntansi Fakultas Ekonomi Universitas Komputer Indonesia: Bandung.

Pratiwi, Dhian Dayinta. "Pengaruh CAR, BOPO, NPF, dan FDR Terhadap Retun On Asset Bank Umum Syariah" Skripsi. Jakarta. 2015.

Rahmat Firdaus. "Manajemen Perkreditan Bank Umum”. Alfabeta. Bandung. 2009.

Rizka. "Perkembangan Perbankan Syariah Di Indonesia", Jurnal. Jakarta. 2015.

Rosadi, Dedi. "Ekonometrika \& Analisis Return Waktu Terapan dengan EViews", ANDI. Yogyakarta. 2012.

Sekaran, Uma. (2011). Research Methods for business Edisi I and 2. Jakarta: Salemba Empat.

Saragih, Arie Firmansyah. "Analisis Perbandingan Kinerja Keuangan Antara Bank Syariah Dengan Bank Konvensional", Vol. 1. No. 1, Jurnal. Penelitian Ilmiah. Medan. 2010.

Sendi Gusnandar Arnan. Imas Kurniawasih,"Pengaruh Jumlah Dana Pihak Ketiga dan Tingkat Non Performing Financing Terhadap Pembiayaan Mudharabah Pada Bank Umum Syariah Di Indonesia", Program Studi Studi Akuntansi, 
Universitas Widyatama, Bandung. 2012.

Shinta Amalina Hazrati Havidz. "Pengaruh Kinerja Keuangan Bank Terhadap Bagi Hasil Simpanan Mudharabah Bank Syariah".Skripsi. Jakarta. 2005

Siregar, Syofian. "Statistika Deskriptif untuk Penelitian", PT Raja Grafindo Persada, Jakarta, 2011.

Sjahdeini, Remy Sutan.1999. Perbankan Islam dan Kedudukannya dalam Tata Hukum Perbankan Indonesia. Pustaka Utama Grafiti. Jakarta.

Subekti dan $\mathrm{R}$ Tjiptosudibio.tt.Kitab Undang-Undang Hukum Perdata. Pradya Pramita, tt. Jakarta.

Sudarsono, Heri. "Bank dan Lembaga Keuangan Syariah Deskripsi dan Ilustrasi", Ekonisia", Yogyakarta. 2004.

Sudiyatno, Bambang. 2010. Analisis Pengaruh Dana Pihak Ketiga, BOPO, CAR dan LDR Terhadap kinerja keuangan pada sektor perbankan yang go public dibursa efek indonesia (BEI), Dinamika Keuangan dan Perbankan, Mei 2010, Hal: 125-137 ISSN: 1979-4878, Vol. 2, No.2.

Sumitro dkk. "Pengantar Ilmu Pendidikan", Universitas Negri Yogyaarta. Fakultas Ilmu Pendidikan. Yogyakarta. 2002.

Sugiyono, 1997, Statistika Untuk Penelitian, Bandung : Alfabeta

Sugiyono, 2010.Metode Penelitian Kuantitatif Kualitatif $\mho$ RND. Bandung : Alfabeta
Suhardjono,"Manajemen Perkreditan Usaha Kecil dan Menengah", Penerbit UPP AMP YKPN, Yogyakarta. 2004.

Suliyanto."Ekonometrika Terapan: Teori e Aplikasi dengan SPSS". Andi, Yogyakarta, 2011.

Surat Edaran Bank Indonesia No. 9/24/DPbS Sistem Penilaian Tingkat Kesehatan Bank Umum Berdasarkan Prinsip Syariah.

Supitasari."Analisis Pengaruh Nisbah Bagi Hasil, BI Rate, Inflasi dan Non Performing Financing Terhadap Simpanan Mudharabah Pada Bank Syariah Di Indonesia Periode 2006-2013", UIN Syarif Hidayatullah. Jakarta. 2014.

Syafi'i Antonio, Bank Syariah Teori dan Praktek (Jakarta, Gema Insani., 2001).

Toni, Dhayat. "Sejarah dan Perkembangan Bank Syariah di Indonesia", Jurnal Ekonomi dan Bisnis. Jakarta. 2013.

Ulfa, Permata. "Analysis The Effect of Profitability (ROA), Cost Ratio (BOPO), and Financing To Deposit Ratio (FDR) On The Profit Sharing Mudarabah In Islamic Banking In Indonesia", Jurnal. Jakarta. 2016.

Warjiyo, Perry. ed. 2004. Bank Indonesia Bank Sentral Republik Indonesia: Sebuah Pengantar. Pusat Pendidikan dan Studi Kebanksentralan. Jakarta.

Winarno, Wing Wahyu. "Analisa Ekonometrika dan Statistika dengan EViews", UPP STIM YKPN, Yogyakarta, 2015. 
Wulandari, Rani. 2012. Pengaruh Financing Deposit To Ratio dan Capital Adequacy Ratio Terhadap Profitabilitas Bank Syariah (Studi Kasus Pada PT Bank Muammalat Indonesia). Universitas Komputer Indonesia : Bandung.

Veithzal Rivai, dkk, Bank dan Financial Institution Managemen Conventional \& Syaria System, (Jakarta : PT. Raja Grefindo Persada, 2007).

Zaibah, Febrina Rizka. "Pengaruh Debt Financing, Equity Financing dan Non Performing Financing Terhadap Profitabilitas Perbankan Syariah". Skripsi UIN Syarif Hidayatullah. Jakarta. 2015.

\section{Peraturan dan Undang-Undang :}

Bank Indonesia http://www.bi.go.id/id/Default.aspx

Bank Indonesia.(2007). Surat Edaran No.9/ 24/DPbs tentang Sistem Penilaian Tingkat Kesehatan Bank Umum Berdasarkan Prinsip Syariah.Jakarta : Bank Indonesia.

Bank Indonesia. Peraturan Bank Indonesia Nomor 9/13/PBI/2007 tentang Kewajiban Penyediaan Modal Minimum Bank Umum dengan Memperhatikan Risiko Pasar, Lembaran Negara Republik Indonesia Tahun 2007 Nomor 128, Tambahan Lembaran Negara Republik Indonesia Nomor 4773.
Bank Indonesia. Peraturan Bank Indonesia Nomor 10/15/PBI/2008 tentang Kewajiban Penyediaan Modal Minimum Bank Umum, Lembaran Negara Republik Indonesia Tahun 2008 Nomor 135, Tambahan Lembaran Negara Republik Indonesia Nomor 4895.

(BASYARNAS (Badan Arbitrase Syariah Nasional).

IAI (Ikatan Akutansi Indonesia) "Akutansi Perbankan", Dewan Standar Akutansi Syariah. Jakarta. 2000.

OJK Laporan Statistik Perbankan Syariah, 2015. Sudarsono, Heri. "Bank dan Lembaga Keuangan Syariah Deskripsi dan Ilustrasi”, Ekonisia, Yogyakarta. 2004.

Republik Indonesia.Undangundang Nomor 10 Tahun 1998 tentang Perubahan Atas Undang-undang Nomor 7 Tahun 1992 tentang Perbankan. 